\title{
4. Water finance: Preparing for the next critical juncture
}

\author{
Diego J. Rodriguez \\ World Bank, United States \\ Amanda McMahon \\ World Bank, United States
}

\begin{abstract}
Water supply, sanitation and irrigation infrastructure provide the critical water services that make economies prosper. The costs of investments in these sectors are low compared to the benefits they provide. By 2025, global water-sector spending will be in the trillions (Organisation for Economic Co-operation and Development (OECD) 2006). By 2050, the pace of urbanisation will be such that achieving universal access to the supply of water and sanitation will cost the developing world an additional one per cent of gross domestic product (GDP) (US $\$ 7.6$ billion) every year compared to current needs (Roehrl 2012). The poorest of these countries, despite their greater need, will have the fewest resources to invest.
\end{abstract}

The 2008 global financial crisis has introduced a new dilemma. As GDP growth slows, so does funding for water services. Credit for developing countries has dried up (World Bank 2013) and current private investment in water services is only about a third the size of development assistance to the sector. Within that slice, international and domestic investors are working with an increasingly narrow list of large, urban areas in middle income countries.

By and large, low-income countries are considered too risky for investment. But with water demand outpacing supply in several large cities, they could become the next growth market for international investors. In order to make private money work to their advantage, these countries will need a sturdy public sector that can promote efficiency and equity in water services and ensure a stable and enabling environment, including institutional, legal and regulatory structures.

It is estimated that more than 75 per cent of all sector funding is provided through public sources, coined by the OECD as the ' 3 Ts', or tariffs, taxes, and transfers. While desirable for funding and maintaining infrastructure (because they don't have to be repaid), each $\mathrm{T}$ has a set of drawbacks that make it less optimal (in many cases) than private sector funding. 
Tariffs are collected directly from households in exchange for water services. If set too low, they risk putting service providers out of business and providing incentives for people to over consume. If set too high, they are not equitable and leave customers dissatisfied.

Tax revenues are provided annually from national or sub-national governments to local service providers. Water budgets change in line with changes to tax revenues, leaving service providers with short-term cash that does not promote long-term investment or incentives to improve performance. A recent study by WaterAid shows that many countries in Africa reduced their budget allocations to water between 2008 and 2010 (WaterAid 2011). Furthermore, most developing countries run their budgets on yearly cycles, creating uncertainty regarding the future tax revenue that will be allocated to water. This is a disincentive for operators to enter into long-term sector planning.

Transfers from donors are well-intentioned but less effective by the time they reach the local service provider. They are as subject to the same volatility as taxes and slower to deliver on promises: sector disbursements average only 70 per cent of commitments. Transfers are also rarely aligned with local capacity to spend the resources. In a $2011 \mathrm{UN}$-water global annual assessment of sanitation and drinking-water GLAAS survey of 38 countries, a meager 18 per cent of participating countries disbursed more than 75 per cent of donor capital commitments to sanitation (World Health Organization (WHO) 2012). This is also exacerbated by the (sometime) discrepancies between donor and country/ sector priorities.

Each of these ' 3 Ts' crystalises the status quo, whereby infrastructure is fixed in the short term without incentivising long-term efficiency improvements or thinking on investment. This arrangement has left poor countries at a critical juncture. Once the world economy starts accelerating again, both private and public funds will rush into the sector. Unless serious reforms are in place, more dollars will go to waste and the status quo could become irreversibly solidified.

Countries need to be ready to make the best use of all their resources by improving water's public sector framework (Rodriguez et al. 2012). First, to protect the public's interest, they need to heed lessons from the history of privatisation in water. This includes sound governance structures, enforced regulations and separation of powers among institutions. Whether the private sector is brought in to improve operations; provide technical assistance; invest in, manage, or own the water infrastructure is irrelevant. The key is having a public sector that is willing to counter-regulate at the same speed: share risk, protect water consumers and maintain control over performance and delivery of results. Second, governments need to drive service providers toward financial sustainability through two means: services that recover most, if not all, of their own costs and more efficient public spending. 
In many developing countries, recovering operational costs will require cutting expenses (through efficiency improvements and reductions in unaccounted for water) and increasing revenues (higher tariffs and better collection rates). Four years of such efficiency improvements helped Uganda's National Water and Sewerage Corporation double its revenues. Reforms were realised through a private sector management structure whereby staff were paid to reach performance targets.

The other side of financial sustainability — government spending — can be improved by more transparent budgeting, long-term investment planning (that integrates the melting pot of funding sources), and hiring the right skill sets to manage spending. To do this requires serious consideration of operating costs and the subsidies that pay for them - where they are going and how they are impacting the daily decisions of consumers and service providers.

While such reforms would make current spending more efficient, governments and donors can do much more to help address the financing gap. They have the power to make service providers more self-sufficient by allowing tariffs to reflect the real cost of services, or providing guarantees and risk-pooling instruments that enable private borrowing. They can also remove the information asymmetries that block private finance from entering the water sector by inventorying assets, mapping out potential water markets, or showcasing creditworthy utilities. More transparency would reduce risks and entice the private sector to court a new market of poor people that is three billion strong and growing. Lastly, they can work together to ensure that grants are allocated based on country and sector needs. This will ensure full ownership of the process.

The Philippines is implementing such game-changing reforms, taking a holistic approach that supports private participation while at the same time strengthening local government capacity to design and implement projects. The government, as financial broker, is pioneering a way to pool the risk (the country is host to 6000 small utilities) and leverage resources toward a more sustainable publicprivate partnership in water. It is worth noting that these advances have been backed by top-level leadership, which is rare in many developing countries.

Whenever it comes, the next influx of cash (and the mechanisms through which it is loaned) will set the pace for a new generation of water infrastructure. Poor countries should take this time to get their financial house in order by designing a sector investment plan like Indonesia's or undertaking a Public Expenditure Review, like Malawi. Such instruments will help public and private interests see the goal, understand the limitations and budget and plan accordingly. They can also provide a framework under which donors and development institutions coordinate at the country level to provide longer budget cycles and more strategic support that aligns with their respective comparative advantages. 
For most low-income countries, simply financing more water infrastructure and services - from public or private sources - will not solve the problem. Changing how the money is budgeted, targeted and executed is the proper place to start.

Dr Diego J. Rodriguez is a Senior Economist at the Water Unit of the Department of Transport, Water and Information and Communication Technology of the Sustainable Development Vice-Presidency of the World Bank. He is the task team leader of the new World Bank initiative on the quantification of the tradeoffs of the energy-water nexus and the program manager of the Water Partnership Program.

Amanda McMahon is a Program Officer in the Water Unit of the Department of Transport, Water and Information and Communication Technology of the Sustainable Development Vice-Presidency of the World Bank. She provides operational support to the Water Partnership Program, a US $\$ 40$ million trust fund that enhances bank operations and analytical work across all water subsectors.

\section{References}

Organisation for Economic Cooperation and Development (OECD), 2006. 'Infrastructure to 2030: Telecom, land transport, water and electricity', OECD, Paris.

Rodriguez, D.J., van den Berg, C. and McMahon, A., 2012. 'Water infrastructure: capital, operations and maintenance sets out a complete reform agenda', World Bank, Washington, D.C.

Roehrl, R.A., 2012. 'Sustainable development scenarios for Rio+20. A component of the sustainable development in the 21st century (SD21) project', United Nations Department of Economic and Social Affairs, Division for Sustainable Development, New York.

WaterAid, 2011. 'Off-track, off-target: why investment in water, sanitation and hygiene is not reaching those who need it most'. Available at: http:// www.wateraid.org/ /media/Publications/water-sanitation-hygieneinvestment.pdf.

World Bank, 2013. 'Global economic prospects', Volume 6, January 2013'. World Bank, Washington, D.C.

World Health Organization, 2012. 'UN-water global annual assessment of sanitation and drinking-water (GlAAS) 2012 report: the challenge of extending and sustaining services'. Available at: http://www.un.org/waterforlifedecade/pdf/ glaas_report_2012_eng.pdf. 
This text taken from Global Water: Issues and Insights by R. Quentin Grafton, Paul Wyrwoll, Chris White and David Allendes, published May 2014 by ANU Press, The Australian National University, Canberra, Australia. 